\title{
КОНЦЕПТУАЛЬНИЙ АНАЛІЗ ІНДИВІДУАЛЬНО-АВТОРСЬКОЇ КАРТИНИ СВІТУ У ФРАНКОМОВНОМУ ПІСЕННОМУ ДИСКУРСІ
}

У статті досліджено індивідуально-авторську картину світу сучасного франкомовного пісенного дискурсу, здійснено його концептуальний аналіз крізь призму текстових концептів, які кодують художньо-авторську ідею твору. Використано методику концептуального аналізу художнього твору та методику дослідження текстових концептів, їх ієрархічної структури, а також методи словникових дефініцій, стилістичного, лексико-граматичного, контекстуально-ситуативного та інтерпретаційного аналізу. Визначено ключовий текстовий концепт художнього простору композиції «Respire»; простежено його розгортання у трьох темпоральних вимірах, представлених у концептуальному просторі франкомовного пісенного дискурсу, проаналізовано лексико-семантичні та стилістичні засоби вербалізації текстових концептів твору, установлено метафоричні й прагматичні властивості текстових концептів обраної композиції. Семантико-когнітивний аналіз ілюстративного матеріалу надав можливість виокремити ключовий текстовий концепт художнього простору ВТРАЧЕНИЙ РАЙ, який у концептуальній ієрархії текстових концептів визначено як мегаконцепт і який розгортається в тексті пісенного твору в трьох темпоральних вимірах: МИНУЛЕ, ТЕПЕРІШНС, МАЙБУТНС, - які виступають мезоконцептами твору. Часові простори МИНУЛЕ та МАЙБУТНС представлені експліцитно, вимір ТЕПЕРІШНС виражено імпліцитно за принципом дзеркального відображення минулого. У структурі мезоконцепту МИНУЛЕ виокремлено мегаконцепти ЖИТТЯ та РАЙ із такими відповідними ката концептами, як: ГАРМОНІЯ й ПРИРОДА. Концепт ТЕПЕРІШНЄ представЛено в мегаконцепті ЗНИЩЕННЯ та катаконцептами НАСИЛЛЯ й ПОНЕВОЛЕННЯ. Концептуальними складниками мезоконецпту ТЕПЕРІШНС виступають емотивні концепти ПЕСИМІЗМ і НЕВПЕВНЕНІСТЬ, а мезоконцепт МАЙБУТНС реалізується в художньому просторі твору в мегаконцепті СМЕРТЬ та відповідних катаконцептах ФІЗИЧНІ ВАДИ й ГОЛОД. Семантико-когнітивний аспект дослідження також дав змогу простежити лінгвальне вираження ключових концептів авторської картини світу, установити концептуальні рівності début=paradis та rien = bien, а також виокремити ключову метафору твору ЖИТТЯ ЯК ГНІЙНА ЯМА.

Ключові слова: концепт, текстовий концепт, художній простір, індивідуально-авторська картина світу, франкомовний пісенний дискурс.

Вступ. Відповідно до когнітивної парадигми художній текст осмислюється як складний знак, що виражає знання письменника про дійсність, утілені в його творі у вигляді індивідуально-авторської картини світу [3, с. 24]. Індивідуальні образно-художні концепти проявляються передусім у результатах естетичної мовленнєвої діяльності, тобто у художніх текстах, де фігурують як одиниці індивідуальної свідомості автора й складові частини його концептуальної системи [2].

Звернення сучасних лінгвістичних розвідок до дослідження текстів малої форми визначається компресією їхніх художніх смислів та їх максимальним образним насиченням [8]. Так, пісенний текст повною мірою репрезентує художню картину світу як результат діяльності авторської свідомості, непрямого відображення дійсності, подекуди девіативного чи аномального [1, с. 5]. Виокремлення ключових когнітивних конструктів (метафор, алюзій, асоціацій), навколо яких формується художній простір музичної композиції, дає змогу тлумачити головні смисли твору й ідейний задум автора.

Однак місце пісенного жанру в культурно-естетичному аспекті не є однозначним. Адже «стилістично пісенний текст маніфестує дві основні тенденції: тяжіння до повсякденної мови та протилежну - тяжіння до стилю «серйозної» поезії. Оскільки пісенний текст інкорпорує як риси розмовно-повсякденного стилю, так і риси поетичного мовлення - епітет, порівняння i метафору, можна стверджувати, що зі стилістичної точки зору пісенний текст є неоднорідним» [8, с. 220]. Проте ми вбачаємо в пісенному творі живу структуру, яка виявляє найвищу здатність гнучко й швидко реагувати на всі зміни, віяння, тенденції, що відбуваються в національній культурі, суспільстві та світовій спільноті загалом, що й визначає актуальність нашого дослідження [8, с. 221].

У цьому контексті лінгвістичний інтерес становить композиція «Respire» французького гурту Mickey 3D, творчість якого має винятково соціальне спрямування. Однією 3 гострих тем сучасності, якої стосується їхня композиція, є тема екологічної ситуації у світі. Це питання $\epsilon$ 
надзвичайно актуальним у наш час, адже в період масового забруднення повітря, води, землі, безмірного використання природних ресурсів, проблема ймовірності продовження людського роду постає дедалі гостріше. Екологи та активісти вдаються до різноманітних засобів і заходів аби привернути увагу громадськості. Учасники гурту вирішили це зробити власним способом. У тексті пісні полярними представлено картини 3 минулого та майбутнього, автори не применшують згубних наслідків байдужої людської поведінки й уникають евфемізмів. Натомість їм удається сконструювати чітко окреслену метафоричну площину, аналіз якої «надає можливість виявити потенціал метафори як ментального процесу при сприйнятті і репрезентації людиною фрагментів світу» [7] та викликати неоднозначність в емоційному сприйнятті тексту слухачем. Останнє можливе завдяки принципу дії когнітивного дисонансу, який визначається як «феномен психологічного незбігу між когнітивними елементами системи знань індивіда, так і власне той психологічний стан дискомфорту, у якому перебуває індивід, переживаючи цю когнітивну суперечність, ідейну суперечливість у людини від побаченого чи почутого» [4, с. 21].

Мета - дослідження індивідуально-авторської картини світу сучасного франкомовного пісенного дискурсу крізь призму текстових концептів, які кодують художньо-авторську ідею. Досягнення мети зумовлює виконання таких завдань: визначити ключовий текстовий концепт художнього простору композиції Respire; простежити його розгортання в трьох темпоральних вимірах, представлених у концептуальному просторі франкомовного пісенного дискурсу, установити ієрархічні зв'язки текстових концептів твору; проаналізувати лексико-семантичні та стилістичні засоби вербалізації текстових концептів твору, виявити метафоричні й лінгвопрагматичні властивості концептуального простору обраної композиції.

Методи та методики дослідження. Концептуальний простір художнього твору інтегрує найважливіші поняття, що слугують реалізації авторських цілей й задуму. Для його дослідження було використано методику концептуального аналізу художнього тексту Л. Г. Бабенко, яка передбачає: а) виявлення набору ключових слів тексту; б) визначення базового концепту (концептів) тексту; в) опис позначуваного ними концептуального простору тексту [3]. Оскільки сутність концептуального аналізу в аспекті його застосування до художнього твору полягає у визначенні та репрезентації змісту його основних смислів, ефективною нам видається методика дослідження текстових концептів О. М. Кагановської, яка наголошує на імпліцитному характері текстових концептів, «зумовленому знаковими властивостями тексту як імені, тобто його кодованим характером» [6, с. 16] та пропонує «розглядати текстові концепти як підпорядковані вершинному текстовому концепту, а саме - мегаконцепту, і відповідно до зниження ступеня узагальненості визначати їх як мезоконцепти, макроконцепти та катаконцепти» [6]. Крім того, у дослідженні застосовано метод словникових дефініцій задля виокремлення спільних семантичних значень лексичних одиниць тексту, методи стилістичного, лексико-граматичного, контекстуально-ситуативного та інтерпретаційного аналізу для виявлення додаткових поняттєво-ціннісних ознак значимих концептів пісенного твору та встановлення концептотвірної ролі лінгвальних засобів у розгортанні текстових концептів художнього простору.

Результати та дискусії. Музична композиція «Respire» вирізняється своєю оповіддю, яка ведеться від першої особи. Оповідач утілює в собі загалом людство майбутнього, для якого наше теперішнє є минулим. Звертаючись до дитини, він розповідає їй ретроспективно історію людства: «Approche-toi petit, écoute-moi gamin, / Je vais te raconter l'histoire de l'être humain» (10). Категорія адресатності виражена прямим звертанням через дієслівні форми у наказовому способі та займенник te (toi). Адресатом свого висловлювання автор обирає малюка зумисне, адже діти - наше майбутнє й надія. Проте у цьому разі прагматична інтенція висловлювання оповідача дещо інша - розповісти про той час, коли людини ще не було на землі, вибачитися за те, що нове покоління його ніколи не зможе пізнати.

Загалом історія людства представлена в пісенному творі трьома темпоральних вимірами: МИНУЛЕ, ТЕПЕРІШНЄ та МАЙБУТНЄ, - серед яких минуле й майбутнє виражені в тексті експліцитно, а теперішнє - імпліцитно. Наприклад, проєкція минулого віднаходить своє лінгвальне втілення в таких уривках: La nature avançait / c'était bien / tu pouvais manger des fruits / $Y$ avait des animaux / les oiseaux revenaient; майбутнє представлено в таких формах: Et tes petits- 
enfants ils n'auront plus qu'un oil / En plein milieu du front / Mais y aura plus personne pour te laver les mains (10). Теперішне потрібно трактувати імпліцитно крізь вимір минулого за принципом дзеркального відображення: через заміну вжитих часових форм (imparfait $\rightarrow$ présent) i протилежність стверджувально-заперечних конструкцій (affirmatif $\leftrightarrow$ négatif). Отже, осмислення теперішнього крізь призму минулого відбувається таким чином: La nature avançait (passé, експліцитне вираження) $\neq$ La nature n'avance plus (présent, імпліцитне вираження) або Y avait pas de chemins (passé, експліцитне вираження) $\neq Y$ a des chemins (présent, імпліцитне вираження).

Часовий контент минулого виражено дієслівними формами в imparfait, що слугує для опису подій у минулому, указує на їх тривалий перебіг: «Au début y avait rien / Au début c'était bien» (10). Це висловлення грунтується на концептуальній рівності rien=bien, яка підсилена анафоричним повтором au début та $\epsilon$ парадоксальною, бо приводить у дію механізм когнітивного дисонансу, адже відсутність чогось не може містити в собі позитивної конотації. Проте саме таким автор бачить життя на землі до приходу людини: ії відсутність була лише на користь планеті.

Концептуального змісту в художньому просторі твору набуває репетитивний лінгвальний конструкт au début, який уживається для позначення виміру минулого, кращого часу на землі. Загалом вислів утілює початок існування світу, цнотливого й неторканого людиною, створює алюзію божественного раю. Концептуально-метафоричне наповнення вислову дає змогу виявити рівність début = paradis, яка актуалізаціє концепт РАЙ у творі.

Додаткові властивості виявленої рівності віднаходимо в іншому фрагменті пісні: La nature avançait / y avait pas de chemins (6). Дві частини фрази є структурними складниками причинно-наслідкових зв'язків. Перша можлива за існування іншої: природа квітла, адже не було дорожніх сполучень. В іншому разі перший структурний елемент був би неможливим. У цьому прикладі ілюстративного матеріалу втіленням незайманого раю є природа, виражена іменником la nature. Дієслово avancer (= aller, se porter en avant [9]), що має значення руху вперед, розвитку та розквіту, указує на позитивний хід речей у світі без людини. Укотре заперечний елемент у структурі розповідного речення містить позитивну конотацію та уможливлює тотожність pas de chemins = bien.

Позитивний конотат у представленні минулого пов'язаний також із присутністю представників фауни: «Y avait des animaux partout dans la forêt, / Au début du printemps, les oiseaux revenaient» (10), а також із гармонією людини з природою, захопленням ії чистотою, блаженством і відчуттям безтурботності людини В такому світі: «Tu leur raconteras l'époque où tu pouvais / Manger des fruits dans l'herbe allongé dans les prés» (10). Ілюстративний матеріал містить у собі обставини місця, що представляють природні локації dans la forêt, dans l'herbe, dans les prés, які доповнюють образ раю. Їх уживання в контексті минулої оповіді свідчить про відсутність їх існування в теперішньому. Образ весни $є$ метафоричним. Це період, який асоціюється 3 поверненням птахів, із пробудженням і відродженням природи та життя загалом. Відсутність птахів навесні символізує порушення у звичному перебігу природних явищ і неможливість їх відновлення. Аналіз ілюстративного матеріалу дав підставу виокремити текстові концепти: ПРИРОДА, ГАРМОНІЯ, ЖИТТЯ. Однак уживання дієслівних форм у контексті МИНУЛОГО нівелює позитивну конотацію висловлювань, що характеризують стан речей у світі, і вказує на його відсутність у теперішньому континуумі, а відтак додає йому концептуального відтінку ВТРАЧЕНОГО Й, отЖе, актуалізує текстовий концепт ВТРАЧЕНИЙ РАЙ.

Різкі зміни в природному середовищі відбуваються 3 появою людини: Puis l'homme a débarqué avec ses gros souliers / Des coups de pieds dans la gueule pour se faire respecter (10). Дієслівний конструкт débarquer (= arriver) має значення небажаного приходу, раптової появи когось, кого не запрошували. Вислів avec ses gros souliers має метафоричне значення й виражає варварський та завойовницький характер такого візиту з деструктивними наслідками й метою знищення. Ілюстративний матеріал містить вислови, що означають фізичне насилля (des coups de pieds = attaque physique avec le pied [9]) та примусу, нав'язування (se faire respecter = imposer une attitude de respect à autrui par son autorité [9]). Результат таких дій людини над природою викладено в такому прикладі: Et tous les éléments se sont vus maîtrisés (10). Дієслово maîtriser (= se rendre maître de qqch par la contrainte physique [9]) вербалізує концептуальне значення 
поневолення, оволодіння із застосуванням фізичної сили. Отже, зазначені лексичні одиниці актуалізують у тексті концепт НАСИЛЛЯ, що характеризує прихід людини та ії вчинки, стан речей у теперішньому часовому просторі.

Текстовий концепт ЗНИЩЕННЯ розгортається в такому уривку: Des routes à sens unique il s'est mis à tracer / Les flèches dans la plaine se sont multipliées (10), де йдеться про негативний вплив на природу діяльності людини, пов'язаної з облаштуванням міст й доріг. Адже будь-яка конструкція передбачає знищення природної локації, винищення лісів, а, як наслідок - загибель їхніх флори та фауни. Забруднення навколишнього середовища i його масштабність також гостро відображено в тексті: On a même commencé à polluer les déserts (10). Прислівник même підсилює парадоксальність ситуації, а також додає емотивності висловлюванню, виражаючи обурення оповідача. Наслідки людської діяльності поклали край існуванню всього живого: En deux temps trois mouvements l'histoire était pliée (10). Дієслово plié вжито в пасивній формі та має значення завершення, кінця життя, а часовий маркер en deux temps trois mouvements (= très rapidement [9]) указує на надзвичайно короткий термін виконання дії. Отже, лінгвальні засоби у фрагментах музичної композиції вербалізують концепти НАСИЛЛЯ, ПОНЕВОЛЕННЯ, ЗНИЩЕННЯ.

Актуалізацію концепту НЕВПЕВНЕНІСТЬ простежуємо в такому прикладі: C'est pas joli joli, et j'connais pas la fin (10). Лексема fin символізує майбутнє, кінець історії оповідача, та в поєднанні $з$ дієслівним конструктом connaître (= знати), ужитому в заперечній формі, виражає невпевненість у майбутньому. На перший погляд, такі сумніви могли би вказувати на оптимістичні настрої та можливість позитивних змін, однак вони спростовуються в наступному тексті: C'est pas demain la veille qu'on fera marche arrière, aбo Il faut que tu respires, c'est demain que tout empire (10). Неможслиість позитивних змін у майбутньому передано через заперечення вислову faire marche arrière (= effectue un mouvement inverse à celui de départ, donc symboliquement que l'on renonce à poursuivre ce que l'on avait commencé [9]), що має значення повернення до початкового стану, а отже, відмови від розпочатих дій, а також дієсловом empirer (= devenir pire [9]), яке містить негативну конотацію та несе значення зміни на гірше. Аналіз уривку ілюстративного матеріалу дав підставу виокремити текстовий концепт ПЕСИМІЗМ, який утілює бачення людей майбутнього.

Автор тексту жорсткий у висловах і проєктуванні виміру МАЙБУТНЄ, але саме в такий спосіб він намагається застерегти наше покоління та спробувати змінити ситуацію на краще, розповідаючи про чудову планету, землю, про втрачений рай, якого не повернути. До свого юного адресата він звертається так: T'es pas né dans un chou mais plutôt dans un trou (10). Вислів être né dans un chou (= народитися в капусті) у заперечній конструкції розвіює дитячі ілюзії про те, як народжуються діти. Натомість автор указує на діру (dans un trou). У розмовній мові лексема trou може набувати таких значень: 1) відсутність, порожнеча (trou = lacune, manque, vide [9]); 2) простір перебільшено малого розміру (trou = lieu dont on veut indiquer la petitesse d'une manière exagérée [9]); або ж місце ув'язнення порушників правил (trou = cachot où sont détenus les prisonniers punis d'infractions aux règles [9]). Загалом, місце народження сучасного покоління в тексті визначено як простір малого розміру, замкнений, порожній, призначений для покарання зловмисників. Концептуально пара лексем сhou і trou становить опозицію, яка актуалізує в тексті антиконцепти РАЙ $\neq$ ПЕКЛО.

Майбутнє покоління він уявляє із фізичними деформаціями, а саме - 3 одним оком посеред чола: Et tes petits-enfants ils n'auront plus qu'un aeil / En plein milieu du front (10). Крім того, людині бракуватиме харчових продуктів, у результаті чого їй доведеться їсти листя: $D^{\prime} i c i$ quelques années on aura bouffé la feuille (10). На граматичному рівні два висловлювання різняться. У першому використано простий майбутній час (le futur simple), який усе ж імплікує сумнів, можливість нереалізації дії за певних умов та передає віддалене майбутнє. У другому ж прикладі висловлювання містить дієслово в складному майбутньому часі (le futur antérieur), який передає дію в близькому майбутньому й виражає впевненість у іiі реалізації. Отже, аналіз лінгвальних засобів фрагментів ілюстративного матеріалу дав підставу виокремити текстові концепти ФІЗИЧНІ ВАДИ та ГОЛОД. 
Кульмінаційною в тексті є метафора ЖИТТЯ ЯК ГНІЙНА ЯМА, представлена в такому уривку: Qu'on remplit tous les jours comme une fosse à purin (10). У тексті гнійна яма, призначена для органічних відходів, урини тощо, для всього того, що раніше було життєдіяльним, $\epsilon$ символом деградації, припинення життєвої діяльності, що є невпинним процесом, про що свідчить часовий маркер tous les jours. У майбутньому кінцевим результатом такого стану речей є лише СМЕРТЬ.

Висновки. Аналіз ілюстративного матеріалу надав можливість виокремити ключовий текстовий концепт художнього простору ВТРАЧЕНИЙ РАЙ, який у концептуальній ієрархії нами визначено як мегаконцепт і який розгортається в тексті пісенного твору в трьох темпоральних вимірах: МИНУЛЕ, ТЕПЕРШШНС, МАЙБУТНС, які виступають мезоконцептами твору. Часові простори МИНУЛЕ та МАЙБУТНС представлені експліцитно, вимір ТЕПЕРШШНС виражено імпліцитно за принципом дзеркального відображення минулого. У структурі мезоконцепту МИНУЛЕ виокремлено мегаконцепти ЖИТТЯ та РАЙ із відповідними катаконцептами: ГАРМОНІЯ Й ПРИРОДА. Концепт ТЕПЕРШШНС представЛено в мегаконцепті ЗНИЩЕННЯ та відповідними катаконцептами НАСИЛЛЯ й ПОНЕВОЛЕННЯ. Концептуальними складниками мезоконецпту ТЕПЕРШШНС виступають емотивні концепти ПЕСИМІЗМ і НЕВПЕВНЕНІСТЬ, а мезоконцепт МАЙБУТНЄ реалізується в художньому просторі твору у мегаконцепті СМЕРТЬ та відповідних катаконцептах ФІЗИЧНІ ВАДИ й ГОЛОД. Семантико-когнітивний аспект дослідження також дав змогу простежити лінгвальне вираження ключових концептів авторської картини світу, установити концептуальні рівності début=paradis i rien=bien, а також виокремити ключову метафору твору ЖИТТЯ ЯК ГНІЙНА ЯМА.

Перспективним видається дослідження концептуальних складників текстових концептів усіх рівнів та визначення їх текстотвірної ролі в художньому просторі франкомовного пісенного дискурсу.

\section{References}

1. Andriyevska, Viktoria. 2013. Anomalniy khudozhniy svit frantsuzkoyi dramaturhiyi absurdyzmu: semantykokohnityvnyi i linhvo-prahmatychnyi aspekty. Lutsk: Vyd. viddil SNU im. Lesi Ukrayinky.

2. Arutyunova, N. D. 1988. "Obraz (opyt kontseptualnogo analiza)". Referentsiya i problemy tekstoobrazovaniya. Moskva: Nauka 117-129.

3. Babenko, L. G., Kazarin, Y. V. 2003. Lingvisticheskiy analiz khudozhestvennogo teksta. Teoriya i praktika. Moskva: Flinta; Nauka.

4. Festinger, L. 2000. Teoriya kohnitivnoho dissonansa. SPb.: Rech.

5. Kaganovska, Olena. 2013. "Mozhlyvi svity i naratyv kriz pryzmu tekstovykh kontseptiv". Naukoviy visnyk Drohobytskogo derzhavnoho pedahohichnoho universytetu imeni Ivana Franka. Ser.: Filologichni nauky (movoznavstvo) 2: 52-57.

6. Kaganovska, Olena. 2002. Tekstovi kontsepty khudozhnoi prozy (na materiali frantsuzkoi romanistyky seredyny XX storichchya). Kyiv: Vyd. KNLU.

7. MaKKormak, E. 2015. "Kognitivnaya teoriya metafory". Teoriya metafory. Moskva, 44-67.

8. Ryabenka, I. 2015. "Verbalizatsiya kontseptu CHAS v anhlomovnomu pisennomu seredovyshchi". Problemy vzayemodiyi mystetstva, pedahohiky ta teorii $i$ praktyky osvity 42: 219-227. URL: http://nbuv.gov.ua/UJRN/Pvmp_2015_42_22.

9. Dictionnaire de français Larousse. https://www.larousse.fr.

Джерело ілюстративного матеріалу

10. Mickey 3D. 2003. Respire. URL: https://www. paroles.net/mickey-3d/paroles-respire.

Андриевская Виктория. Концептуальный анализ индивидуально-авторской картины мира во французском песенном дискурсе. В статье исследуется индивидуально-авторская картина мира современного франкоязычного песенного дискурса, его концептуальный анализ сквозь призму текстовых концептов, которые кодируют художественно-авторскую идею произведения. Используется методика концептуального анализа художественного произведения и методика исследования текстовых концептов, их иерархической структуры, а также методы словарных дефиниций, стилистического, лексико-грамматического, контекстуально-ситуативного и интерпретационного анализа. Определяется ключевой текстовый концепт художественного пространства в композиции «Respire»; прослеживается его развертывание в трех темпоральных измерениях, представленных в концептуальном пространстве франкоязычного песенного дискурса, анализируются лексико-семантические и стилистические средства вербализации текстовых концептов произведения, устанавливаются метафорические и прагматические свойства текстовых концептов выбранной композиции. Семантико-когнитивный анализ иллюстративного материала предоставил возможность выделить ключевой текстовый концепт художественного пространства ПОТЕРЯННЫЙ РАЙ, который в концептуальной иерархии текстовых концептов определяется как 
мегаконцепт и разворачивается в тексте песенного произведения в трех темпоральных измерениях: ПРОШЛОЕ, НАСТОЯЩЕЕ, БУДУЩЕЕ, которые выступают мезоконцептами произведения. Временные пространства ПРОШЛОЕ и БУДУЩЕЕ представлены эксплицитно, измерение НАСТОЯЩЕЕ выражено имплицитно по принципу зеркального отражения прошлого. В структуре мезоконцепта ПРОШЛОЕ выделяются мегаконцепты ЖИЗНЬ и РАЙ с соответствующими катаконцептамЫ: ГАРМОНИЯ и ПРИРОДА. Концепт НАСТОЯЩЕЕ представлен в мегаконцепте УНИЧТОЖЕНИЕ и катаконцептамЫ НАСИЛИЯ и ПОРАБОЩЕНИЯ. Концептуальными составляющими мезоконецпту НАСТОЯЩЕЕ выступают эмотивные концепты ПЕССИМИЗМ и НЕУВЕРЕННОСТЬ, а мезоконцепт БУДУЩЕЕ реализуется в художественном пространстве произведения в мегаконцепте СМЕРТЬ и соответствующих катаконцептах ФИЗИЧЕСКИЕ НЕДОСТАТКИ и ГОЛОД. Семантикокогнитивный аспект исследования также позволил проследить лингвальное выражение ключевых концептов авторской картины мира, установить концептуальные равенства début = paradis и rien = bien, а также выделить ключевую метафору произведения ЖИЗНЬ КАК ГНОЙНАЯ ЯМА.

Ключевые слова: концепт, текстовый концепт, художественное пространство, индивидуально-авторская картина мира, франкоязычный песенный дискурс.

Andriievska Viktoriia. Conceptual Analysis of the Individual Author's Picture of the World in the French Song Discourse. The article is devoted to the study of the individual author's picture of the world of the modern French song discourse, its conceptual analysis through the prism of textual concepts that encode the artistic author's idea of the work. The method of conceptual analysis of a artistic work and the method of studying textual concepts, their hierarchical structure, as well as methods of dictionary definitions, stylistic, lexical and grammatical, contextual and situational and interpretive analysis were used. The key textual concept of the artistic space in the composition «Respire» has been determined; traced its deployment in three temporal dimensions, presented in the conceptual space of the French song discourse, analyzed the lexical, semantic and stylistic means of verbalizing the textual concepts of the work, established the metaphorical and pragmatic properties of the textual concepts of the selected composition. Semantic and cognitive analysis of the illustrative material provided an opportunity to highlight the key textual concept of the artistic space LOST PARADISE, which in the conceptual hierarchy of textual concepts is defined as a mega-concept and unfolds in the text of a song work in three temporal dimensions: PAST, PRESENT, FUTURE, which are meso-concepts. Temporary spaces PAST and FUTURE are presented explicitly, dimension PRESENT is expressed implicitly according to the principle of mirror reflection of the past. In the structure of the meso-concept of the PAST, the mega-concepts of LIFE and PARADISE are distinguished with the corresponding cata-concepts: HARMONY and NATURE. The concept of PRESENT is presented in the mega-concept DESTRUCTION and the cataconcept of VIOLENCE and SUBMISSION. The conceptual components of the meso-concept of the PRESENT are the emotive concepts of PESSIMISM and UNCERTAINTY, and the meso-concept FUTURE is implemented in the artistic space of the work in the mega-concept DEATH and the corresponding cata-concepts PHYSICAL FAULTS and HUNGER. The semantic and cognitive aspect of the study also made it possible to trace the lingual expression of the key concepts of the author's picture of the world, to establish conceptual equalities beginning is paradise and nothing is good, and also to highlight the key metaphor of the work LIFE AS A PUSH PIT.

Key words: concept, textual concept, artistic space, individual author's picture of the world, French song discourse.

DOI: https://doi.org/10.32782/2410-0927-2020-13-2

УДК 378:371.311:811.11

Юлія Баклаженко

\section{ЛІНГВІСТИЧНІ ПЕРЕДУМОВИ НАВЧАННЯ АНГЛІЙСЬКОГО ПРОФЕСІЙНО ОРІЕНТОВАНОГО ПИСЕМНОГО МОВЛЕННЯ В ЗАКЛАДАХ ВИЩОЇ ОСВІТИ}

Навчання професійно орієнтованого писемного мовлення як засобу віддаленої комунікації та професіоналізації відіграє сьогодні значну роль у зв'язку з високими вимогами до підготовки фахівців ыз різних галузей знань. У статты розглянуто лінгвістичні передумови навчання англійського професійно орієнтованого писемного мовлення у закладах вищої освіти. Зокрема, окреслено характерні відмінності професійно орієнтованого технічного, академічного та творчого письма як комунікативних актів; визначено екстралінгвістичні й власне мовні риси професійно орієнтованого писемного мовлення, такі як точність викладу, лаконічність, доступне оформлення документа; орієнтованість на аудиторію, граматична, лексична та змістова правильність тексту. Виявлено, що для навчання професійно орієнтованого писемного мовлення важливе врахування таких характерних рис, як використання термінології, точність значення, усталений порядок слів у фразах, використання сталих висловів, застосування слів із вираженим технічним забарвленням, використання складних і складених лексем, утворених за різними моделями, застосування абревіатур, скорочень, пасивних конструкцій, інфінітива, герундія та герундіальних конструкцій, дієприкметника та дієприкметникових конструкцій. Зазначено також труднощі лінгвістичного характеру, із якими стикаються студенти під час написання текстів на професійно-технічну тематику.

(C) Баклаженко Ю., 2020 